\title{
Late Jurassic-Early Cretaceous freshwater bivalves from Turiasaurus riodevensis bearing strata of Teruel (Spain)
}

\author{
Graciela DELVENE ${ }^{*}$, Martin MUNT ${ }^{2}$, Rafael ROYO-TORRES ${ }^{3}$, Alberto COBOS ${ }^{3}$ \& Luis \\ ALCALÁ ${ }^{3}$
}

\footnotetext{
${ }^{1}$ Museo Geominero, Instituto Geológico y Minero de España, c/ Ríos Rosas, 23, E-28003 Madrid, Spain; g.delvene@igme.es

${ }^{2}$ Dept. of Earth Sciences, The Natural History Museum, Cromwell Road, London SW7 5BD, United Kingdom; m.munt@ nhm.ac.uk

${ }^{3}$ Fundación Conjunto Paleontológico de Teruel-Dinópolis, Museo Aragonés de Paleontología, Avda. Sagunto s/n, E-44002 Teruel, Spain; royo@dinopolis.com; cobos@dinopolis.com; alcala@dinopolis.com
}

* Corresponding author

Delvene, G., Munt, M., Royo-Torres, R., Cobos, A. \& Alcalá, L. 2013. Late Jurassic-Early Cretaceous freshwater bivalves from Turiasaurus riodevensis bearing strata of Teruel (Spain). [Bivalvos de agua dulce del Jurásico Superior-Cretácico Inferior asociados a los niveles de Turiasaurus riodevensis (Teruel, España)]. Spanish Journal of Palaeontology, 28 (2), $161-172$.

\begin{abstract}
Three freshwater bivalve taxa are described from the Villar del Arzobispo Formation (Late Jurassic-Early Cretaceous) of Riodeva, Teruel, Spain. The stratigraphic range of the large and geographically widely distributed bivalve Margaritifera, previously recorded from the Early Cretaceous of Spain and southern England, is recognised to extend back probably into the Late Jurassic. This new record extends the palaeogeographic and temporal distribution of the family Margaritiferidae in Europe.
\end{abstract}

Keywords: Margaritiferidae, Tithonian-Berriasian, Riodeva (Teruel), Europe.

\section{RESUMEN}

Se describen tres taxones de bivalvos de agua dulce de la Formación Villar del Arzobispo (Jurásico Superior-Cretácico Inferior) de Riodeva, Teruel, España. La distribución de los bivalvos incluidos en Margaritifera tenían un registro temporal durante el Cretácico Inferior en España y el sur de Inglaterra, siendo ahora ampliado probablemente hasta el Jurásico Superior. Los nuevos datos aquí presentados aumentan la distribución paleogeográfica y registro temporal de la familia Margaritiferidae en Europa.

Palabras clave: Margaritiferidae, Tithoniense-Berriasiense, Riodeva (Teruel), Europa. 


\section{INTRODUCTION}

Non-marine bivalves from Barrihonda-El Humero at Riodeva (Southern Iberian Range), famous for the occurrence of Turiasaurus riodevensis Royo-Torres, Cobos \& Alcalá, 2006 and other dinosaur fossils (RoyoTorres et al., 2006, 2009; Cobos et al., 2010; Gascó et al., 2012) were first recorded by Delvene et al. (2010). The material includes Margaritifera and specimens showing chevron-shaped ornamentation, whose taxonomy is discussed here. Unfortunately, most of specimens are poorly preserved; however, the probably Late Jurassic date makes it the earliest occurrence of different groups of Unionoida to date in Spain. This paper presents a detailed description and discussion of the taxa (Table 1) and their palaeobiogeographical implications.

Table 1. List of the studied specimens from the Villar del Arzobispo Fm (Fig. 2) of Riodeva (Teruel, Spain).

\begin{tabular}{lll}
\hline \multicolumn{1}{c}{ Specimen } & \multicolumn{1}{c}{ Site } & Log interval \\
\hline CPT-1964 & RD-34, Están de Colón & Interval A \\
CPT-1514 (1-2) & $\begin{array}{l}\text { RD-10, Barrihonda- } \\
\text { El Humero }\end{array}$ & Interval B \\
& RD-10, Barrihonda- & \\
CPT-1516 & El Humero & Interval B \\
& RD-10, Barrihonda- & \\
CPT-1517 & E1 Humero & Interval B \\
CPT-1563 & RD-10, Barrihonda- & \\
CPT-1819 (1-3) & RD-26, Oncolithes & Interval B \\
CPT-4401 & RD-10-833 & Interval A \\
CPT-4402 & RD-10-834 & Interval B \\
CPT-4403 & RD-10-831 & Interval B \\
CPT-4404 & RD-10-832 & Interval B \\
CPT-4405 & RD-10-835 & Interval B \\
\hline
\end{tabular}

\section{GEOGRAPHICAL AND GEOLOGICAL SETTING}

The Riodeva sites (Fig. 1) are located in the southern Iberian Range, in the province of Teruel, north-eastern Spain. The fossils come from the Villar del Arzobispo Formation which comprises an approximately 200-m-thick succession of sandstone and red silty clay (Fig. 2). The outcrops occur in an $18 \mathrm{~km}^{2}$ triangular depression, which has been cut by deeply incised stream channels. To the east of these exposures, folded Jurassic limestones form higher ground, while to the west and north unconformable Cretaceous and Tertiary deposits overlay the Riodeva deposits (Luque et al., 2005). The Villar del Arzobispo Formation is underlain by oncolithic limestone of the
Higueruelas Formation, which gradually passes into the transitional deposits of the Villar del Arzobispo Formation. This succession has been interpreted by Bádenas \& Aurell $(2001,2010)$ to represent a regressive phase traceable over large parts of the Iberian basin. At Riodeva a shallowingupward tendency is clearly recognisable by the increase in coarser siliciclastic materials towards the top. The Villar del Arzobispo Formation is overlain unconformably by the Barremian Collado Sands and Limestones Formation (Luque et al., 2005; Alcalá et al., 2009). It consists of continental and transitional deposits representing deltaic plans in a deposition system controlled by fluvial processes (Mas et al., 1982; Vilas et al., 1982).

At Riodeva, the Villar del Arzobispo Formation comprises a minimum of thirteen cycles, each composed of 2-10 m thick, white-yellowish sandy beds overlaid by similarly thick beds of red and gray silty clays (Luque et al., 2005). The base of each sequence is sharp and erosional. Palaeocurrent analysis indicates dominant currents in NW-SE and NE-SW directions. Luque et al. (2005) divided the formation in Riodeva area into (A) a basal portion comprised of tidally influenced siliciclasticcarbonatic deposits that gradually evolved from the underlying shallow marine carbonates; (B) an intermediate siliciclastic succession with carbonates at its base, still tidally influenced, but becoming more fluvial in the upper part; and (C) thin carbonate levels at the top, which suggest a return to more marine conditions (Fig. 2). The second, thickest interval has yielded dinosaur remains. The bivalve fauna described herein come from unit A at the Oncolithes (RD-26) and mainly in unit B at the Barrihonda-El Humero (RD-10) and Están de Colón (RD-34) sites (Fig. 2).

\section{TAPHONOMICAL ASPECTS}

The sites are located in channel facies. In RD-10, the sands are laterally replaced by clays and in this boundary we found the bivalves with different grade of fragmentation and preservation. Bones of dinosaurs appear mainly in clays but also in sandstones, they are broken and occur with ferruginised plant remains. In RD-34 the layer is composed primarily of sands and partially by microconglomerates. RD-26 has a more marine influence composed by carbonatic layers with oncolithes of small size $(1-10 \mathrm{~mm})$. The bivalves are associated with infilling of channels of estuarine origin (Alcalá et al., 2009).

Studied bivalves can be grouped as three types of: 1) Best preserved specimens consist of single valves or fragments of them. Internal and external features can be observed, shell thickness can be measured. Posterior part of the shells are broken, this kind of preservation is very common in freshwater bivalves because it is the thinnest part of the shell and therefore very fragile. 2) Internal moulds, relatively eroded, of articulated specimens with 


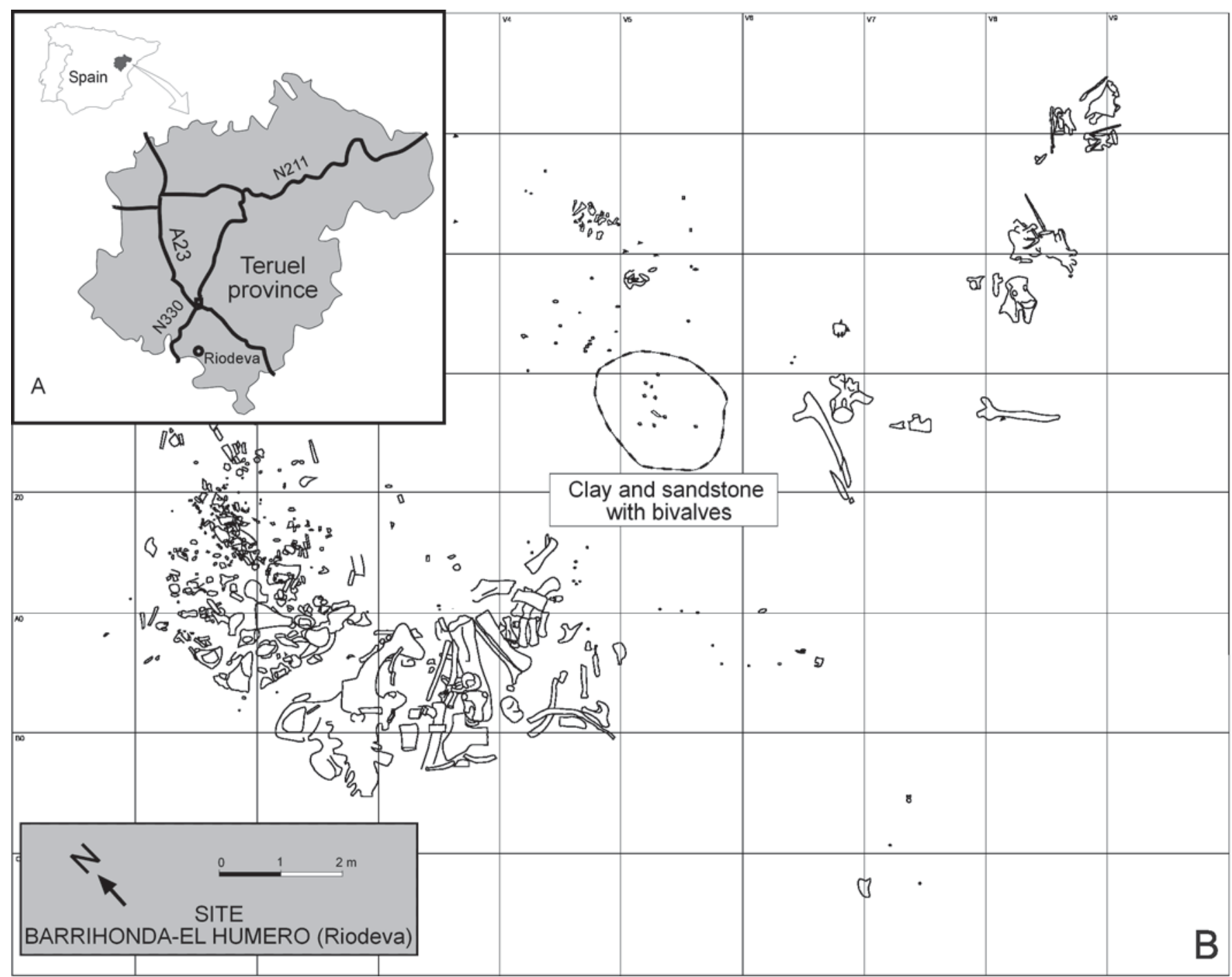

Figure 1. A) Geographic position of Riodeva. B) Map of excavation at the Barrihonda-El Humero site (RD-10) showing position of bivalves.

impressions of ligament insertions. 3) Composite moulds of articulated specimens, with valves slightly displaced, in butterfly position. The term "composite mould" is used in sense of McAlester (1962). This author proposed the use of "composite mould" for fossils which combine features of both the interior and exterior of the shell. Although the term was suggested specifically for Palaeozoic bivalves, it can be used for the rest of fossils. This preservation is explained by means of compression of external and internal moulds, which maintain together both parts, superimposing internal and external moulds. This kind of fossil is possible in single valves, articulated elements (McAlester, 1962: plate 16), both opened or closed valves. External details of many composite moulds suggest that the matrix was plastic when the impression was made, implying the early remove of the original shell. McAlester (1962) suggests that the main composition of this kind of composite moulds is aragonitic or dominantly aragonitic, and it is the case of our studied specimens.

\section{AGE OF THE VILLAR DEL ARZOBISPO FORMATION}

The lack of biochronological markers has meant that the age of the Villar del Arzobispo Formation at Riodeva has yet to be firmly established. However, at its stratotype located in Valencia province -Villar del Arzobispo villagethis formation has yielded the middle Kimmeridgian to early Berriasian foraminifera Alveosepta jaccardi, Anchispirocyclina lusitanica and Evertycyclamina virguliana (Mas et al., 1984; Aurell, 1990; Bádenas \& Aurell, 2010). Recently, Bádenas et al. (2008-2009) and Bádenas \& Aurell (2010), based upon foraminifera, dated the base of the Villar del Arzobispo Formation as near the Kimmeridgian-Tithonian boundary in the westernmost outcrops in the Griegos-Frías-Jabaloyas area and Middle Tithonian in the Riodeva area (Fezer, 1988; Bádenas et al., 2008-2009; Bádenas \& Aurell, 2010). The biochronological data suggest that the Villar del Arzobispo Formation is 


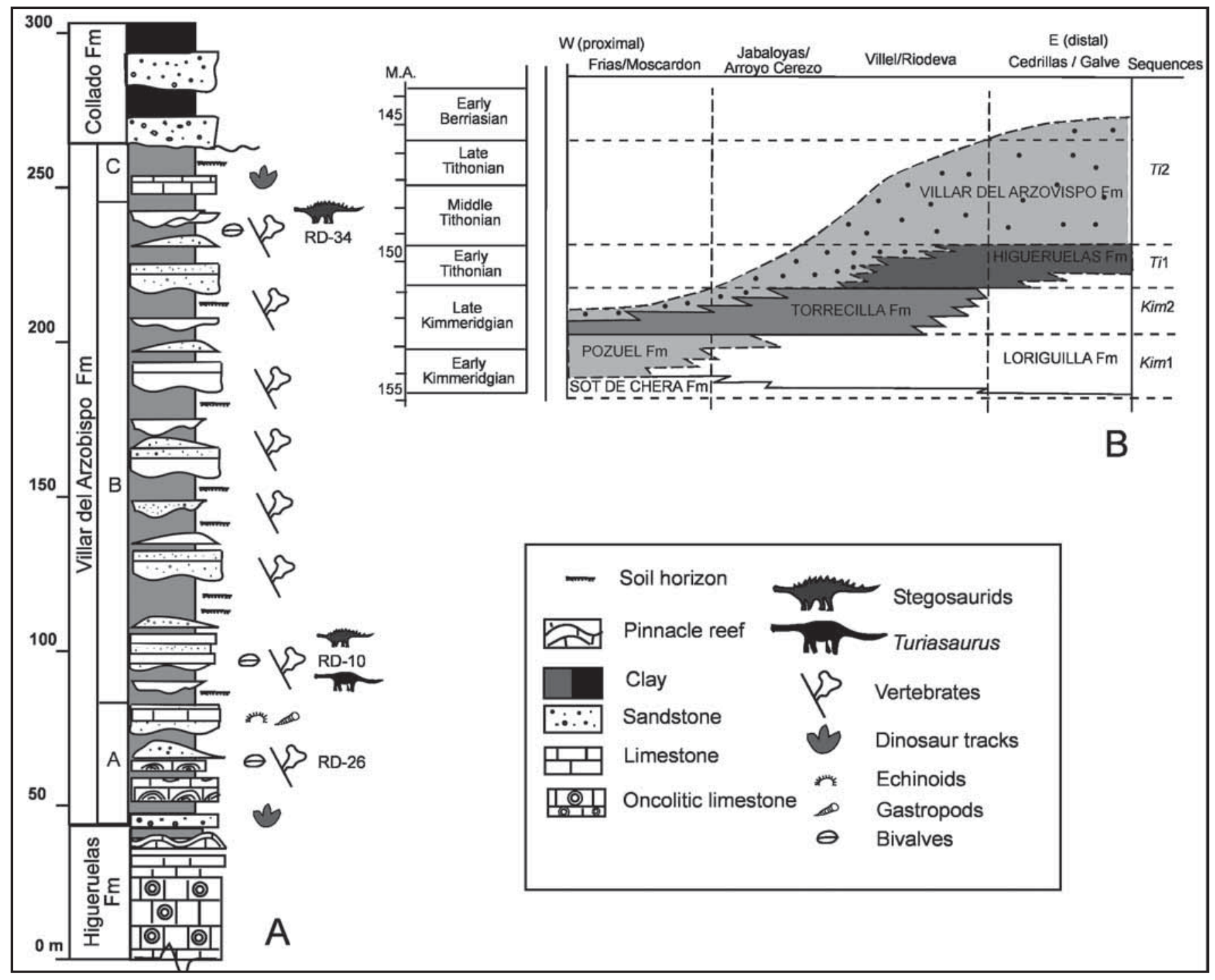

Figure 2. A) Stratigraphic section of Riodeva (modified from Luque et al., 2005). B) Summary of the stratigraphy of the Late Jurassic in the marginal areas of the Iberian Basin around Teruel (Bádenas \& Aurell, 2010).

diachronous, which is typical of a sedimentary succession displaying regressive trend (Bádenas \& Aurell, 2010). The underlying Higueruelas Formation at Riodeva contains the foraminifera Anchispirocyclina lusitanica, indicating that the dinosaur-bearing deposits are no older than Tithonian (Fezer, 1988). The lack of biochronological markers, the erosional surface at the top, and the sedimentary hiatus overlying the Riodeva succession do not allow precise age determination of the uppermost exposures of the Villar del Arzobispo Formation in Riodeva, but stratigraphic correlation (Fig. 2) infers a Middle - Late Tithonian age (Gautier \& Viallard, 1966; Bádenas et al., 2008-2009; Bádenas \& Aurell, 2010). So the age of the Villar del Arzobispo Formation in Riodeva is inferred to be Middle Tithonian to Early Berriasian (Luque et al., 2005) or Middle to Late Tithonian (Bádenas et al., 2008-2009; Bádenas \& Aurell 2010). Moreover, the dinosaur faunas are considered to be characteristic of the Late Jurassic (Royo-Torres et al., 2009; Cobos et al., 2010; Gascó et al., 2012).

\section{PALAEOENVIRONMENT}

The Villar del Arzobispo Formation shows a general regressive trend (Mas et al., 1984; Bádenas \& Aurell, 2001), which can be attributed to global regression recorded during the Late Jurassic in the Iberian Basin (Haq et al., 1987; Hallam, 2001; Ford \& Golonka, 2003). The terrigenous deposits containing the fauna were mainly deposited in subtidal, supratidal, and tidal environments. Cyclic processes, possibly climate-forced, gave rise to a series of shallowing upward parasequences showing marine influenced deposits at the base and more continental deposits at the top. 
At Riodeva the parasequences usually start with a fine and well laminated sandstone at the base, occasionally this has a temporal meaning, including a thin layer of limestone rich in ostreids, and occasionally gastropods, echinoids, and fine plant remains. This indicates a marine influence. Often these sands are thick with large-scale cross-bedding in the middle part. Higher in the parasequence conglomerates alternate with red and grey clays and occasional paleosols, which can be related to overbank deposition on a muddy supratidal flat to alluvial plain.

The bivalves from Barrihonda-El Humero (RD-10) were found in exposures of sandstones and overlying the grey clays. The site has yielded the remains of the large sauropod Turiasaurus riodevensis, stegosaurids such as Dacentrurus, teeth of theropods, and a basal ornithopod. Additionally, isolated crocodile teeth, partially articulated turtles, abundant fish teeth and scales and plant remains have also been found (Royo-Torres et al., 2006, 2009; Cobos et al., 2010; Gascó et al., 2012; Cobos \& Gascó, 2013).

\section{SYSTEMATIC PALAEONTOLOGY}

Institutional abbreviations. CPT, for the fossil material deposited at the Museo Aragonés de Paleontología (Fundación Conjunto Paleontológico de Teruel-Dinópolis); NHMUK, for The Natural History Museum, London. Although poorly preserved this material is outstanding because it is the oldest record of the Unionoidea to date in Spain and the ?Trigonioidoidea in Europe. Delvene et al. (2010) cited the first recorded non-marine bivalves from the site RD-10 (Barrihonda-El Humero, Riodeva, Teruel, Spain) with preliminary observations of the material described here.

Systematic palaeontology follows partially Carter et al. (2011):

Megaorder UNIONATA J. Gray, 1854

Order UNIONOIDA Stoliczka, 1871

Family Margaritiferidae Haas, 1940

Genus Margaritifera Schumacher, 1816

Type species: Mya margaritifera Linnaeus, 1758 by monotypy following ICZN article 68.3.

\section{Margaritifera cf. valdensis (Mantell, 1844)}

(Figs 3A-3G)

Material. The material comprises four isolated valves consisting of neomorphosed calcite: two fragmented left valves (CPT-1819 (3) and CPT-1964); one shell fragment (CPT-1819 (1)); a shell fragment assigned to right valve with some doubts (CPT-1819 (2)). Size measurements are given in Table 2 . The best preserved bivalve shells have been collected from units A and C of the Villar del Arzobispo Formation at Riodeva (Teruel, Spain).
Table 2. Size measurements (in $\mathrm{mm}$ ) of Margaritifera $\mathrm{cf}$. valdensis from Riodeva (Teruel, Spain).

\begin{tabular}{clccc}
\hline Specimen & Preservation & Length & Height & Thickness \\
\hline CPT-1819 (1) $\begin{array}{l}\text { Fragment of } \\
\text { ventral region }\end{array}$ & - & - & - \\
CPT-1819 (2) & $\begin{array}{l}\text { Shell fragment } \\
\text { of ?right valve }\end{array}$ & - & - & $5.2 \mathrm{~mm}$ \\
CPT-1819 (3) & $\begin{array}{l}\text { Fragmented left } \\
\text { valve }\end{array}$ & - & $+45.4 \mathrm{~mm}$ & $5.3 \mathrm{~mm}$ \\
& $\begin{array}{l}\text { Left valve, } \\
\text { posterior and } \\
\text { dorsal-posterior } \\
\text { areas broken }\end{array}$ & $+85 \mathrm{~mm}$ & $81 \mathrm{~mm}$ & $13 \mathrm{~mm}$ \\
CPT-1964 & & & \\
\hline
\end{tabular}

\section{Synonymies.}

cf. * 1844 Unio valdensis sp. nov. Mantell, p. 403, figs $1,2,3$.

cf. 1846 Unio valdensis Mantell; J. de C. Sowerby, pl. 646 , figs $1,2,3$.

cf. 1961 "Unio" valdensis Mantell; Mongin, p. 340, pl. 15, pl. 16, figs 1a, $1 \mathrm{~b}$.

cf. ?1961 "Unio" valdensis Mantell; Mongin, pl. 16, fig. 2.

cf. 1966 Margaritifera (Pseudunio) valdensis Mantell; Mongin, p. 44.

cf. 1998 Margaritifera (Pseudunio) valdensis (Mantell); Radley \& Barker, figs 3a, 7.

cf. 2009a Margaritifera valdensis (Mantell, 1844); Delvene \& Araujo, fig. 3: 6, fig. 4, fig. 5: 1-3.

* Type species

\section{Type material.}

Lectotype: NHMUK PI OR 32581; Mantell Collection; separate valves of a single specimen (Mantell, 1844: $\mathrm{p}$. 603-604, figs.1-3).

Syntype: NHMUK PI OR 32582; Mantell Collection; paired valves.

Type locality: Brook Point, Isle of Wight.

Type stratum: Wealden Beds (=Wessex Formation, Wealden Group).

Description. Shell large-sized, greater than $85 \mathrm{~mm}$ in length, up to $81 \mathrm{~mm}$ in height, shell elongate-oval in outline, inequilateral, shell thickness reaching up to 13 $\mathrm{mm}$. Anterior part short and convex, posterior area not preserved, therefore, neither lateral teeth. The umbo, which is set anteriorly, is broad and rounded. The dentition of the left valve comprises two crenulated pseudocardinal teeth, very strong in the larger specimen. Muscle impression seems to be arborescent (Figs 3D-3E). Part of the pallial line visible in some specimens (Figs 3B, 3F). Mantle 


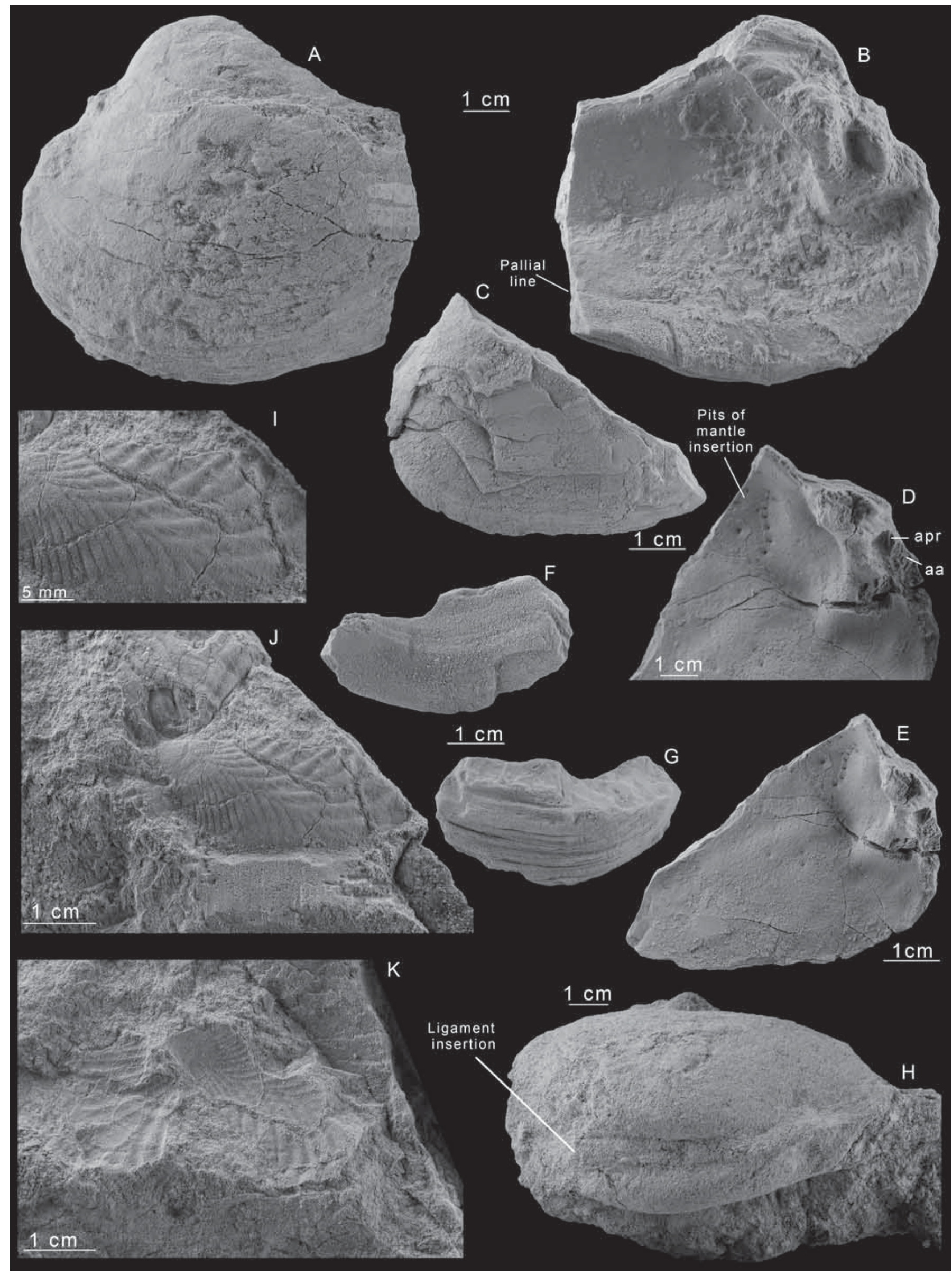


attachment scars (or pits of mantle insertion) discernable in one of the specimens (Figs 3D-3E). They are located below the umbonal region, and run obliquely from the anterior to the posterior of the shell. External shell covered with strong, irregular commarginal growth lines, which are more crowded on the ventral part of the flank.

Remarks. The characters seen in this material (outline, hinge features, and mantle attachment scars) allow assignment to the genus Margaritifera. The specimens show strong similarity to the well known Margaritifera valdensis from the Early Cretaceous of southern England, but due to the poor preservation, we prefer to ascribe it to this species with some doubt. Margaritifera valdensis was reviewed by Mongin (1961), based upon the types of Unio valdensis Mantell, 1844 from the Wealden of South England. Mongin recognised that $M$. valdensis was distributed across Lower Cretaceous localities including the Wealden of Germany, Spain and the Sahara, although some of these identifications require re-evaluation. Despite the probable Tithonian age of the specimens we find no basis to place them in any another species and/or genus. This is the earliest occurrence of Margaritifera in Spain to date. In common with many unionids, Margaritifera displays high morphological variability, with at least two morphotypes recognised by Delvene \& Araujo (2009a). The two morphotypes of M.valdensis were based on the great difference of thickness of the shell and ligament. The first morphotype includes the lectotype (NHMUK PI OR 35281) and syntype (NHMUK PI OR 32582) described by Mantell (1844), with a thickness of 12.65 $\mathrm{mm}$ on the thicker area. The second morphotype includes the specimen NHMUK PI LP744 whose thickness and ligament is thinner (c. $8.00 \mathrm{~mm}$ ) than the former. The new record from Riodeva shows this morphological variability very well. The specimen from unit C (CPT-1964), an adult specimen, has a very thick shell and matches the first morphotype (similar to lectotype and syntype). The remaining specimens from unit A belong to second morphotype (NHMUK PI L 9744), as do the other Spanish specimens illustrated by Delvene \& Araujo (2009a).

Remarks about Pseudunio. Mongin (1966) included M. valdensis in the subgenus Pseudunio (1966: p. 342) distinguishing it from Margaritifera s. str. The main differences that she observed in Pseudunio were a thicker shell, heavier hinge, and presence of two posterior lamellae in the left valve. Some authors such as Chepalyga (1965) and Schneider \& Prieto (2011) accept the difference between both subgenera (Pseudunio and Margaritifera). However, Araujo et al. (2009: p. 13), using molecular data to clarify the phylogeny of Margaritiferidae, have placed doubt on the validity of the subgenus Pseudunio. Delvene \& Araujo (2009a) described M. valdensis from the Cameros Basin of the Lower Cretaceous from Spain, ascribing it solely to Margaritifera. Based upon morphological characters, Araujo et al. (2009: p. 21) demonstrated that the extant species Margaritifera margaritifera has lateral teeth in the juvenile stage which they loose during their life, resulting in vestigial traces or absence in adults. Thus, this main character is highly variable, and should not be used as character to differentiate Pseudunio and Margaritifera.

\section{Unionoida indet.}

Large unionids (Table 3, Fig. 3H) from unit B preserved as internal moulds of articulated specimens were tentatively ascribed to Margaritifera valdensis by Delvene et al. (2010), based on shape, growth lines, and external ligaments. However, due to their poor preservation we prefer to consider them as an indeterminate unionoid until more specimens are found which confirm the previous determination.

Table 3. Measurements (in mm) of "unionoid", taxon very close to $M$. cf. valdensis from Riodeva (Teruel, Spain).

\begin{tabular}{clccc}
\hline Specimen & Preservation & Length & Height & Convexity \\
\hline CPT-1514 (1) & $\begin{array}{l}\text { Articulated } \\
\text { internal mould }\end{array}$ & $98.9 \mathrm{~mm}$ & $+50.3 \mathrm{~m}$ & $32.9 \mathrm{~mm}$ \\
CPT-1514 (2) & $\begin{array}{l}\text { Articulated } \\
\text { internal mould }\end{array}$ & - & $45.6 \mathrm{~mm}$ & - \\
& $\begin{array}{l}\text { Articulated } \\
\text { internal mould }\end{array}$ & $64.6 \mathrm{~mm}$ & $42.9 \mathrm{~mm}$ & $19.4 \mathrm{~mm}$ \\
CPT-1563 & $\begin{array}{l}\text { Articulated } \\
\text { internal mould }\end{array}$ & $113.7 \mathrm{~mm}$ & $51.9 \mathrm{~mm}$ & - \\
CPT-4401 & $\begin{array}{l}\text { Fragmented } \\
\text { articulated } \\
\text { internal mould }\end{array}$ & - & $39.3 \mathrm{~mm}$ & - \\
CPT-4402 & & & \\
\hline
\end{tabular}

Remarks about ornamented unionoids. European Jurassic freshwater bivalves are poorly known and most often ascribed to weakly ornamented or smooth forms attributed

Figure 3. A-G) Margaritifera cf. valdensis (Mantell 1844). (A) External view of a left valve, CPT-1964. (B) Internal view of the same specimen, note the pallial line. (C) External view of a left valve, CPT-1819 (3). (D, E) Internal views of the same specimen, apr: anterior pedal retractor; aa: anterior adductor. (F) Internal view of a ventral fragment, CPT-1819 (1). (G) External view of the same specimen. H) Unionoida indet. Internal mould of articulated specimen, posterior end at left. Note the ligament insertion, CPT-1514 (1). I-K) ?Trigonioidoidea indet. I) Detail of the posterior ornamentation, CPT-1516. J) Composite mould of left valve and part of the right one in "butterfly position". K) External mould of the same specimen. 
to 'Unio' sensu lato. Recent studies of European freshwater fossils are clarifying the taxonomy and palaeogeography of this group of bivalves. From Portugal the Choffat collection of Middle to Upper Jurassic unionids from of Cap Mondégo and Pombal among other classical localities, have been recently examined, showing that common commarginal and two-lobed umbonal ornamentation since that age. In fact, it is relatively common; evident two-lobed ornamentation is present in $U$. cf. mayeri, $U$. heberti, $U$. setubalensis, $U$. veziani, U. delgadoi, U. buarcosensis and U. heimi. Choffat (1885: pl. 1, figs 7-9) ascribed a group of specimens of medium size (45 $\mathrm{mm}$ of length) to Unio mayeri. The best preserved specimen is a right valve (Choffat, 1885: pl. 1, fig.7), which interiorly shows mantle pits (Fig. 4A). Its exterior ornamentation (Fig. 4B) consists of irregular ribs conmarginal up to the umbo, and from, 16 irregular and winding divaricated ribs cover the posterior part of the flank, dividing into posteriorly directed secondary ribs. The specimen figured by Choffat (1885: pl. 1, fig. 8) is not clear and its identificaction is doubtful. However, a left valve figured by him on pl. 1, fig. 9 shows the arborescent anterior aductor muscle scar relatively joined to the anterior pedal retractor (Fig. 4C). Therefore, shells with mantle pits, not separated anterior adductor and anterior pedal retractor, and posterior radial and divaricated ornamentation should be ascribed to Margaritifera. This means that Margaritifera existed at least since the Lower Kimmeridgian in Europe, and its shell may be ornamented exteriorly. Another kind of ornamentation in Jurassic Portuguese bivalves has been observed in $U$. heimi (Choffat, 1885: pl. 2, fig. 27) consisting of several very slight $\mathrm{V}$-shaped ribs, just below the umbo (Fig. 4D). Unfortunately, the posterior part is smooth and partially broken; the taxonomy of this specimen is doubtful at the moment. Chepalypa (1965) analysed the ornamentation in extant and fossil Margaritiferidae and noted that the tendency for folding of ribs towards the posterior part of the shell occurs since the Early Miocene in European species (see Schneider \& Prieto, 2011) and Late Cretaceous in North-American ones. According to Chepalypa (1965), the folding decreases in Pliocene forms to almost disappear in Quaternary ones in Europe. In contrast, in North America the evolution of this type of ornamentation is much more irregular and appears/ disappears at different times and places. In our opinion, ornamented margaritiferids are present at least since the Jurassic, but the why this ornamentation developed is not yet clear.

Another important European record is Unio andersoni from the Great Estuarine Series, Middle Jurassic, of the Inner Hebrides, which, according to Hudson (1963), is unornamented except for faint growth-rugae. Other European Unioinod freshwater bivalves with only umbonal ornamentation or smooth flanks have been described from Spain by Delvene \& Araujo (2009a, 2009b) and England by Munt et al. (2011).
Ornamentation is much more complex and developed in the Trigonioidoidea. This is a very characteristic group of bivalves, considered unionoids by many authors (Carter et al. 2011). It has traditionally been thought that its occurrence was restricted to Asian, but it has been subsequently recognised from the Wealden of southern England by Barker \& Munt (1993) and Barker et al. (1997) expanding its palaeogeographic record. Delvene \& Munt $(2009,2011$, in press) and Delvene et al. (2009, 2011) have found some new taxa from Early Cretaceous rocks of Spain in three separate areas; the Cameros Basin, the Central Iberian Range, and the Aliaga sub-basin. Trigonioidoidea are defined on the basis of the diagnostic anterior musculature (anterior aductor separated from anterior pedal retractor) according to Sha \& Fürsich (1993) and Sha (2007). Therefore, complex ornamentation is not restricted solely to this group of bivalves, with other groups of Unionoida may also develop radial ornamentation, such as the margaritiferids. Mantle attachment scars below the umbo in an anterior to posterior direction are characteristic of the Margaritiferidae (Smith, 1983). As in many cases it is not possible to observe the interior of bivalves, distinguishing between Unionoidea and Trigonioidoidea is not easy (see below).

\section{? Trigonioidoidea indet. (Figs 3I-3K)}

\section{Order TRIGONIIDA Dall, 1889}

Superfamily TRIGONIOIDOIDEA Cox, 1952 [nom. corr. Kolesnikov, 1977]

Material. Two articulated specimens preserved as composite moulds (CPT-1516 and CPT-1517) from RD10, Barrihonda-El Humero site (unit B). Three articulated internal moulds (CPT-4403; CPT-4404; CPT-4405) from the same level show some relicts of very faint ornamentation and are therefore also included in this superfamily with doubts.

Description. The best preserved specimen (CPT$1516,3.4 \mathrm{~mm}$ minimum of length) comprises positive and negative imprints of a pair of valves, which are preserved in slightly displaced butterfly position. The left valve is better preserved, and the part which comprises the posterior flank displays distinctive reversed V-shaped ribs forming an angle of $72^{\circ}$. The posterior set of the ribs of the chevrons are coarser than those of the anterior set. Posterior of the umbo (actually almost eroded) the ribs are fine, becoming broader and coarser towards the shell margins. Fourteen ribs are seen in the specimen, of which only the most distal five from umbo form clear chevrons. These are much coarser than the ribs located anteriorly, the most posterior/ventral sets showing signs of bifurcation. The remaining ribs, towards the anterior part of the shell, 




Figure 4. Sketch based on own photographs of some specimens of the Choffat collection. A-C) Unio mayeri. Choffat 1885. (A) Interior view of a right valve. Figured by Choffat (Pl. 1, fig. 7b). Note pallial line and pits of mantle insertion. (B) Exterior view of the same specimen. Figured by Choffat (P1. 1, fig. 7a). Note exterior ornamentation. (C) Interior of a left valve. Figured by Choffat (Pl. 1, fig. 9), apr: anterior pedal retractor; aa: anterior adductor; pp: pedal protactor. D) Unio heimi Choffat, 1885. Exterior of a right valve figured by Choffat (Pl. II, fig. 27). Scale bar $=5 \mathrm{~mm}$.

are obliquely arranged most likely being the $d$ posterior part of the V-shaped ornamentation on the flank but this we cannot demonstrate as the anterior area is incomplete.

Remarks. Despite the poor preservation of our specimens, we think that the high angle of reversed V-shaped ribs does not indicate a margaritiferid-type ornamentation in which the angle is much less than $70^{\circ}$ and usually the central and anterior parts of the shell is smooth. Commonly, ribs of margaritiferids slope towards the posterior part differently, but occasionally this direction can be variable and some specimens of Margaritifera flabellata (pers. observ.) carry some ribs directed straight towards the ventral margin. We interpret that the anterior set of ribs of our specimens form the posterior part of the V-shaped ornamentation on the flank and as they are oblique slightly towards the anterior part of the shell. However, we do state that due to not being able to examine the anterior muscle scars of the specimens we can not confirm this identification with $100 \%$ confidence. Future studies of Spanish Jurassic freshwater Unionoida, at the moment in process, will clear up the evolution of the ornamentation and distribution pattern of Unionoida.

\section{CONCLUSIONS}

The bivalve fauna from the Villar del Arzobispo Formation (Middle and Late Tithonian to Early Berriasian) of Riodeva comprises two taxa. Margaritifera $\mathrm{cf}$. valdensis (Mantell, 1844), previously recorded from the Early Cretaceous of Spain and southern England, is recognised extending its stratigraphic range back into the Late Jurassic. Some poorly preserved specimens assigned to the ?Trigonioidoidea, based on fragmented material, constitutes the earliest record of this superfamily in Europe. The occurrence of Margaritifera valdensis in the Berriasian Ashdown Formation of the Wealden Group of southern England (Munt et al., 2011), suggests that it extended its distribution northwards probably during the latest Jurassic and earliest Cretaceous. The new record of ?Trigonioidoidea consolidates the evidence of a European 
lineage of the group distributed since Late Jurassic times. The new findings support the hypothesis that these Unionoida migrated into northern Europe from Iberia.

\section{ACKNOWLEDGMENTS}

This study is a contribution to the projects CGL200911838 and CGL2009-07792, co-financed by FEDER funds (Government of Spain) and the FOCONTUR project (Research Group E-62, Departamento de Industria e Innovación, Aragón Government and Fondo Social Europeo). This study is one of the palaeontological research projects subsidised by the Departamento de Educación, Universidad, Cultura y Deporte, Aragón Government. The excavations at Riodeva were funded by its Dirección General de Patrimonio Cultural (Exp. 252/02/2003, 142/2003, 142/03/2004, 197/2005, 241/2006, 314/2006, 201/2007, 168/2007, 225/2008, 079/2009, 104/2010). Photographs were prepared by the Servicio de Fotografía Paleontológica of the University of Zaragoza (Spain). G. Delvene received support from the SYNTHESYS Project (http://www.synthesys.info/), financed by the European Community Research Infrastructure Action under the FP7 Integrating Activities Programme. M. Munt acknowledges the support of the Palaeontology Investment Fund of the former Department of Palaeontology, The Natural History Museum. G. Delvene thanks Dr. Winfried Werner (Bayerische Staatssammlung für Paläontologie und Geologie, Munich, Germany) for his help and availability for consulting freshwater bivalve collections, and Prof. M. Ramalho (Museu Geológico del LNEG de Portugal) for his availability for examination of the Choffat collection in Lisbon. This work has been financed partially by the Geological Survey of Spain, Instituto Aragonés de Fomento, and Fundación Conjunto Paleontológico de Teruel-Dinópolis. Authors thank to Prof. F.T. Fürsich, Dra. A. Márquez-Aliaga for the revision of the manuscript, and the associate editor Dr. M. Reolid.

\section{REFERENCES}

Alcalá, L., Cobos, A., Delclòs, X., Luque, L., Mampel, L. \& Royo-Torres, R. 2009. Mesozoic terrestrial ecosystems in Teruel. In: Mesozoic terrestrial ecosystems in Eastern Spain (coords. Alcalá, L. \& Royo-Torres, R.). ¡Fundamental!, 10, 94-130.

Araujo, R., Reis, J., Machordom, A., Toledo, C., Madeira, M.J., Gómez, I., Velasco, J.C., Morales, J., Barea, J.M., Ondina, P. \& Ayala, I. 2009. Las náyades de la Península Ibérica. Iberus, 27 (2), 7-72.

Aurell, M. 1990. El Jurásico Superior de la Cordillera Ibérica central (provincias de Zaragoza y Teruel) Análisis de Cuenca. PhD dissertation, University of Zaragoza, Zaragoza, Spain.

Bádenas, B. \& Aurell, M. 2001. Kimmeridgian palaeogeography and basin evolution of northeastern Iberia. Palaeogeography, Palaeoclimatology, Palaeoecology, 168, 291-310.

Bádenas, B. \& Aurell, M. 2010. Facies models of a shallowwater carbonate ramp based on distribution of non-skeletal grains (Kimmeridgian, Spain). Facies, 56, 89-110.

Bádenas, B., Aurell, M., Ipas, J. \& Espilez, E. 2008-2009. Las plataformas del final del Jurásico al suroeste de la provincia de Teruel: evolución de facies y secuencias de alta frecuencia. Teruel, 92, 67-96.

Barker, M. J. \& Munt, M. C. 1993. Nippononaia sp. nov. a new freshwater bivalve from the Wessex Formation of the Isle of Wight. University of Portsmouth, Department of Geology, Report of Activities, 15, 44-46.

Barker, M. J., Munt, M. C. \& Radley, J. D. 1997. The first recorded Trigonioidoidean bivalve from Europe. Palaeontology, 80, 955-963.

Carter, J.G., Altaba, C.R., Anderson, L.C., Araujo, R., Biakov, A.S., Bogan, A.E., Campbell, D.C., Campbell, M., Chen, J-H., Cope, J.C.W., Delvene, G., Dijkstra, H.H., Fang, Z-J., Gardner, R.N., Gavrilova, V.A., Goncharova, I.A., Harries, P.J., Hartman, J.H., Hautmann, M., Hoeh, W.R., Hylleberg, J., Jiang, B-Y., Johnston, P., Kirkendale, L., Kleemann, K., Koppka, J., Kříž, J., Machado, D., Malchus, N., Márquez-Aliaga, A., Masse, J-P., Mcroberts, C.A., Middelfart, P.U., Mitchell, S., Nevesskaja, L.A., Özer, S., Pojeta, J.Jr., Polubotko, I.V., Pons, J.M., Popov, S., Sánchez, T., Sartori, A. F., Scott, R.W., Sey, I.I., Signorelli, J.H., Silantiev, V.V., Skelton, P.W., Steuber, T., Waterhouse, J.B., Wingard, G.L. \& Yancey, T. 2011. A Synoptical Classification of the Bivalvia (Mollusca). University of Kansas Publications. Paleontological contributions New Series, 4, 47.

Chepalyga, A.L. 1965. Fossil Margaritifera of Moldavia and southern Ukraine. International Geology Review, 7, 1847-1857.

Choffat, P. 1885-1888. Description de la faune jurassique du Portugal. Mollusques Lamellibranches. 2e ordre. Asiphonida. Mémoires de la Direction des Travaux géologiques du Portugal, 115.

Cobos, A. \& Gascó. F. 2013. New vertebral remains of the stegosaurian dinosaur Dacentrurus from Riodeva (Teruel, Spain). Geogaceta, 53, 17-20.

Cobos, A., Royo-Torres, R., Luque, L., Alcalá, L. \& Mampel, L. 2010. An Iberian stegosaurs paradise: The Villar del Arzobispo Formation (Tithonian-Berriasian) in Teruel (Spain). Palaeogeography, Palaeoclimatology, Palaeoecology, 293, 223-236.

Delvene, G. \& Araujo, R. 2009a. Early Cretaceous nonmarine bivalves from the Cameros and Basque-Cantabrian basins of Spain. Journal of Iberian Geology, 35, 19-34.

Delvene, G. \& Araujo, R. 2009b. Protopleurobema: a new genus of freshwater bivalve from the Lower Cretaceous of the Cameros basin (NW Spain). Journal of Iberian Geology, 35, 169-178. 
Delvene, G. \& Munt, M. 2009. Trigonioidoidea (Unionoida) from the Lower Cretaceous of Spain. $8^{\text {th }}$ International Symposium on the Cretaceous System, p. 61-62.

Delvene, G. \& Munt, M. 2011. New Trigonioidoidea (Bivalvia; Unionoida) from the Early Cretaceous of Spain. Palaeontology, 54, 631-638.

Delvene, G. \& Munt, M. in press. Mollusca. In: Las Hoyas a Lower Cretaceous exceptional deposit from the Iberian Peninsula (eds. Poyato-Ariza, F., Buscalioni, A.D. \& Fregenal-Martinez, M.). Pfeil Verlag.

Delvene, G., Munt, M. \& Sender, L.M. 2009. First record of Trigonioidoidea from the Lower Cretaceous of Spain. 10th International Symposium on Mesozoic Terrestrial Ecosystems and Biota, p. 131-132.

Delvene, G., Munt, M. \& Sender, L.M. 2011. Iberanaia iberica: the first record of the Trigonioidoidea (Unionoida, Bivalvia) from the Lower Cretaceous of Teruel, Spain. Cretaceous Research, 32 (5), 591-596.

Delvene, G., Munt, M., Royo-Torres, R., Cobos, A. \& Alcalá, L. 2010. Non-marine bivalves from the dinosaur-bearing strata of Riodeva (Teruel). V Congreso de Jurásico de España (Colunga, Asturias), p. 57.

Fezer, R. 1988. Die oberjurassische karbonatische Regressionsfazies im Südwestlichen Keltiberikum zwischen Griegos und Aras de Alpuente (Pro. Teruel, Cuenca Valencia and Spanien). Arbeiten aus dem Institut für Geologie und Paläontologie an der Universität Stuttgart, 84, 1-119.

Ford, D. \& Golonka, J. 2003. Phanerozoic paleogeography, paleoenvironment and lithofacies maps of the circumAtlantic margins. Marine and Petroleum Geology, 20, 249-285.

Gascó, F., Cobos, A., Royo-Torres, R., Mampel, L. \& Alcalá., L. 2012. Theropod teeth diversity from the Villar del Arzobiso Formation (Tithnian-Berriasian) at Riodeva (Teruel, Spain). Palaeobiodiversity and Palaeoenvironments, 92, 273-286.

Gautier, F. \& Viallard, P. 1966. Sur le Jurassique terminal et le Crétacé du Nord de la province de Valencia (Espagne). Comptes rendus de l'Académie des Sciences, Serie D, 262, 432-435.

Hallam, A. 2001. A review of the broad pattern of Jurassic sea-level changes and their possible causes in the light of current knowledge. Palaeogeography, Palaeoclimatology, Palaeoecology, 167, 23-37.

Haq, B. U., Hardenbol, J. \& Vail, P. R. 1987. Chronology of fluctuating sea levels since the Triassic (250 million years ago to present). Science, 235, 1156-1167.

Hudson, J.D. 1963. The ecology and stratigraphical distribution of the invertebrate fauna of the Great Estuarine Series. Palaeontology, 6, 327-348.

Luque, L., Cobos, A., Royo-Torres, R., Espilez, E. \& Alcalá, L. 2005. Caracterización de los depósitos sedimentarios con dinosaurios de Riodeva (Teruel). Geogaceta, 38, 27-30.

Mantell, G. A. 1844. On the Unionidae of the river of the country of the Iguanodon. The American Journal of Science and Arts, 47, 402.
Mas, J. R., Alonso, A. \& Meléndez, N. 1984. La Formación Villar del Arzobispo: un ejemplo de llanuras de marea siliciclásticas asociadas a plataformas carbonatadas. Jurásico terminal (NW de Valencia y E de Cuenca). Publicaciones de Geología, Universidad Autónoma de Barcelona, 20, 175-188.

Mas, J. R., Alonso, A. \& Meléndez, N. 1982. El Cretácico basal "Weald" de la Cordillera Ibérica Suroccidental (NW de la provincia de Valencia y E de la de Cuenca). Cuadernos de Geología Ibérica, 8, 309-335.

Mc Alester, A. L. 1962. Mode of preservation in early Paleozoic pelecypods and its morphologic and ecologic significance. Journal of Paleontology, 36, 69-73.

Mongin, D. 1961. "Unio" valdensis Mantell, from the Wealden beds of England: its taxonomic position and geographical distribution. Proceedings of the Malacological Society of London, 34, 340-345.

Mongin, D. 1966. Description paleontologique de quelques lamellibranches limniques des facies wealdiens d'Espagne. Notas y Comunicaciones del Instituto Geológico y Minero de España, 91, 41-60.

Munt, M.C., Radley, J.D. \& Barker, M.J. 2011. Molluscs. In: English Wealden fossils (ed. Batten, D.J.), Palaeontological Association Field Guide to Fossils, Palaeontological Association, Dorchester, 88-108.

Radley, J.D. \& Barker, M.J. 1998. Palaeoenvironmental analysis of shell beds in the Wealden Group (Lower Cretaceous) of the Isle of Wight, southern England: an initial account. Cretaceous Research, 19, 489-504.

Royo-Torres, R., Cobos, A. \& Alcalá, L. 2006. A giant European dinosaur and a new sauropod clade. Science, 314, 1925-1927.

Royo-Torres, R., Cobos, A., Aberasturi, A., Espílez, E., Fierro, I., González, A., Luque, L., Mampel, L. \& Alcalá, L. 2009. High European sauropod dinosaur diversity during Jurassic-Cretaceous transition in Riodeva (Teruel, Spain). Palaeontology, 52, 1009-1027.

Schneider, S. \& Prieto, J. 2011. First record of an autochthonous community of fluviatile freshwater molluses from the Middle/Late Miocene Upper freshwater molasse (southern Germany). Archiv für Molluskenkunde, 140, 1-18.

Sha, J. 2007. Cretaceous trigonioidid (non-marine Bivalvia) assemblages and biostratigraphy in Asia with special remarks on the classification of Trigonioidacea. Journal of Asian Earth Sciences, 29, 62-83.

Sha, J. \& Fürsich, F.T. 1993. Bivalve faunas of eastern Heilongjiang, northeastern China. I. Non-marine Bivalvia of the Xiachengzi Formation (Lower Cretaceous). Beringeria, 8, 139-187.

Smith, D.G. 1983. On the so-called mantle muscle scars on shell of the Margaritiferudae (Mollusca, Pelecypoda), with observations on mantle-shell attachment in the Unionoida and Trigonoida. Zoologica Scripta, 12, 67-71.

Sowerby, J de C. 1846. The Mineral Conchology of Great Britain. Plates 644-648, London.

Vilas, L., Mas, R., García, A., Arias, C., Alonso, A., Meléndez, N. \& Rincón, N. 1982. Ibérica Suroccidental. In: El Cretácico de España (ed. García, A.), Editorial Complutense, Madrid, 457-514. 
